\title{
IMPLEMENTASI EUFEMISME DALAM BERITA UTAMA SURAT KABAR TEMPO SEBAGAI BAHAN AJAR BAHASA INDONESIA DI SMP
}

\author{
Rahma Eka Septiana ${ }^{1}$, Laili Etika Rahmawati ${ }^{2}$ \\ Pendidikan Bahasa dan Sastra Indonesia \\ Universitas Muhammadiyah Surakarta \\ Surakarta, Indonesia \\ e-mail: A310170035@student.ums.ac.id ${ }^{1}$,Laili.Rahmawati@ums.ac.id ${ }^{2}$
}

\begin{tabular}{|l|c|c|}
\hline (C) (P) & \multicolumn{3}{|c|}{$\begin{array}{l}\text { This is an open-access article under the CC BY-SA license. } \\
\text { Copyright }(2021 \text { by Author. Published by Universitas Pendidikan Ganesha. }\end{array}$} \\
\hline Received : April, 2021 & Accepted : June, 2021 & Published : June, 2021 \\
\hline
\end{tabular}

\begin{abstract}
ABSTRAK
Penelitian ini bertujuan untuk mendiskripsikan implementasi eufemisme dalam berita utama surat kabar Tempo sebagai bahan ajar bahasa Indonesia di SMP. Penelitian ini menggunakan metode penelitian deskriptif kualitatif. Teknik pengumpulan data yang digunakan yaitu teknik baca dan catat. Teknik baca dilakukan dengan cara membaca teks berita yang terdapat dalam surat kabar Tempo dan teknik catat dilakukan dengan cara mencatat katakata atau kalimat-kalimat yang termasuk dalam penggunaan eufemisme dalam berita utama surat kabar Tempo. Hasil penelitian ini adalah penggunaan eufemisme dalam berita utama surat kabar Tempo. Penggunaan eufemisme dapat diimplementasikan sebagai bahan ajar bahasa Indonesia. Ungkapan eufemisme dapat ditemukan dalam unsur-unsur teks berita.
\end{abstract}

Kata-kata kunci : eufemisme; berita utama; surat kabar; Tempo; bahan ajar

\section{ABSTRACT}

This study aims to describe the implementation of euphemisms in the headlines of the Tempo newspaper as a teaching material for Indonesian in SMP. This research uses descriptive qualitative research methods. The data collection techniques used were reading and note taking techniques. The reading technique is done by reading the news text contained in the Tempo newspaper and the note taking technique is done by recording words or sentences that are included in the use of euphemisms in the main news of the Tempo newspaper. The result of this research is the use of euphemisms in the headlines of the Tempo newspaper. The use of euphemisms can be implemented as Indonesian language teaching materials. The expression euphemisms can be found in the elements of the news text.

Keywords: euphemism; headlines; newspapers; Tempo; teaching materials

\section{PENDAHULUAN}

Kompetensi yang perlu dimiliki oleh guru dalam melaksanakan tugas mengajar salah satunya adalah mengembangkan bahan ajar. Pengembangan bahan ajar penting dilakukan guru agar pembelajaran lebih efektif, efisien, dan terstruktur sesuai dengan kompetensi yang ingin dicapai. Mata pelajaran Bahasa Indonesia merupakan mata 
pelajaran yang wajib ditempuh disemua jenjang pendidikan tanpa terkecuali. Kurikulum 2013 menempatkan Bahasa Indonesia sebagai penghela mata pelajaran lain dan karenanya harus berada di depan semua mata pelajaran lain (Rimayanti dan Jaja, 2018). Perancangan pembelajaran bahasa Indonesia selain untuk memproduksi dan menggunakan teks sesuai fungsi dan tujuan sosialnya, juga memberi ruang kepada peserta didik untuk mengembangkan berbagai ilmu struktur berpikir, karena setiap teks memiliki struktur berpikir yang berbeda satu sama lain (Delisnawati, dkk, 2019).

Materi mata pelajaran Bahasa Indonesia yang didalamnya terdapat banyak ungkapan eufemisme yaitu teks berita. Teks berita diajarkan di kelas VIII dengan bahasan unsur-unsur, struktur, dan kebahasaan. Struktur-struktur tersebut tersusun secara runtut yang akhirnya membentuk sebuah teks yang utuh (Pendari dan Amril, 2019). Salah satu surat kabar yang menggunakan eufemisme dalam menyampaikan berita adalah surat kabar Tempo. Penggunaan eufemisme dalam berita dimaksudkan untuk menghindari kata-kata yang menyinggung, merendahkan seseorang, menghina dan menimbulkan kepanikan.

Eufemisme dalam teks berita dapat implementasikan sebagai bahan ajar bahasa Indonesia khususnya pada jenjang sekolah menengah pertama agar terhindar dari disfemisme atau kata yang memiliki makna kasar. Dengan adanya eufemisme, akan mempengaruhi cara berkomunikasi peserta didik dengan orang lain karena kegiatan bertutur di dalam kelas berbeda dengan kegiatan bertutur di masyarakat secara alamiah. Di kelas terdapat tata krama, sopan santun, dan budi pekerti yang merupakan aspekaspek bahasa yang diapresiasikan oleh sebuah komunikasi yang dilingkupi oleh berbagai konteks (Badelah, dkk, 2019). Dalam berbahasa, manusia juga melakukan pertimbangan seperti penegasan, kesopanan, penghormatan, rasa jengkel, dan lain sebagainya (Sagala, 2020). Pembelajaran bahasa Indonesia memiliki peranan penting bagi siswa. Pembelajaran ini bertujuan agar peserta didik memiliki kemampuan berkomunikasi secara efektif dan efisien sesuai dengan etika yang berlaku. Selain itu, pembelajaran ini bertujuan untuk melatih peserta didik terampil berbahasa dengan menuangkan ide dan gagasannya secara kreatif dan kritis (Hidayatullah, dkk, 2018)

Berita menyajikan informasi aktual yang sedang terjadi melalui media cetak, siaran, internet, atau dari mulut ke mulut. Laporan berita harus berupa terkini yang dipilih secara sengaja oleh redaksi pemberitaan atau media untuk disiarkan dengan anggapan bahwa berita yang terpilih dapat menarik khalayak banyak karena mengandung unsur-unsur berita (Hidayat, 2011). Adanya unsur-unsur berita, pembaca dapat langsung mengetahui berita yang dibaca. Namun, berita-berita yang digunakan untuk media pembelajaran di dalam buku teks tidak aktual, sehingga berita dalam surat kabar Tempo dapat digunakan sebagai contoh teks berita untuk bahan ajar bahasa Indonesia. Melalui bahan ajar, pembelajaran akan memperoleh pengalaman berhubungan dengan fakta berupa fakta-fakta dalam kehidupan, model-model kehidupan, dan simbol-simbol yang dipakai dalam kehidupan (Sriasih, dalam Sukmawati, dan Agus, 2018).

Penelitian implementasi eufemisme sebagai bahan ajar telah dilakukan peneliti terdahulu antara lain Setiawaty dan Agus (2018) "Bentuk dan Fungsi Eufemisme Dalam Komentar Akun Facebook Presiden Joko Widodo Sebagai Bahan Ajar Bahasa Indonesia" dengan hasil penelitian menunjukkan bahwa pertama, bentuk-bentuk eufemisme dalam komentar akun Facebook Presiden Joko Widodo. Kedua, fungsi eufemisme dalam komentar akun Facebook Presiden Joko Widodo. Ketiga, eufemisme 
dalam akun Facebook Presiden Joko Widodo dapat dimanfaatkan sebagai bahan ajar dalam pembelajaran bahasa Indonesia pada kurikulum 2013 kelas VIII dalam KI.4 dan KD.4.1 mengenai teks diskusi.

Febrianjaya, et al (2013) "Penggunaan Eufemisme dan Disfemisme pada Tajuk Rencana Serta Implikasinya Terhadap Pembelajaran" dengan hasil penelitian penggunaan eufemisme dan disfemisme pada tajuk rencana Radar Lampung dan Lampung Post lebih banyak menggunakan disfemisme. Penelitian ini berimplikasi pada pembelajaran bahasa Indonesia di SMA. Terutama pada pembelajaran berbicara, yaitu menyampaikan kritik dan persetujuan atau dukungan.

Hubungan penelitian ini dengan penelitian sebelumnya yaitu sama-sama meneliti implementasi eufemisme sebagai bahan ajar dan pembelajaran bahasa Indonesia. Perbedaan penelitian ini dengan dua penelitian sebelumnya terletak pada objek dan subjek yang dikaji. Peneliti Setiawaty dan Agus (2018) meneliti eufemisme yang terdapat pada akun Facebook Presiden Joko Widodo dan materi ajar yang dipilih adalah teks diskusi jenjang SMP. Febrianjaya, et al (2013) meneliti eufemisme yang terdapat pada Radar Lampung dan Lampung Post, pelajaran yang dipilih adalah kemampuan berbicara di jenjang SMA. Penelitian ini membahas implementasi eufemisme dalam berita utama surat kabar Tempo sebagai bahan ajar bahasa Indonesia di SMP. Alasan peneliti memilih judul tersebut adalah penghalusan kata atau kalimat sebagai pembentuk moral baik kepada peserta didik khususnya jenjang SMP karena memberikan dampak positif untuk perkembangan wawasan.

\section{METODE PENELITIAN}

Penelitian ini menggunakan jenis penelitian deskriptif kualitatif. Data yang dianalisis bukan berupa data angka-angka (data kualitatif) melainkan berupa kata-kata (Mahsun, 2014). Penulis menggunakan metode penelitian ini dengan tujuan mengetahui implementasi eufemisme dalam berita utama surat kabar Tempo sebagai bahan ajar di SMP.

Data penelitian ini berupa teks berita utama surat kabar. Data kualitatif adalah data yang dinyatakan dalam bentuk kata, kalimat, dan gambar (Sugiyono, 2006). Sumber data penelitian ialah subjek darimana data dapat diperoleh (Arikunto, dalam Putri, 2020). Sumber data yang digunakan yaitu sumber data primer dan sekunder. Sumber data primer adalah data yang berasal dari sumber asli atau pertama (Narimawati, 2008). Sumber data primer berupa eufemisme dalam berita utama surat kabar Tempo. Sumber data sekunder merupakan sumber data yang tidak langsung memberikan data kepada pengumpul data, misalnya lewat orang lain atau lewat dokumen (Sugiyono, 2011). Sumber data sekunder penelitian ini berupa buku-buku dan jurnal-jurnal yang berkaitan dengan analisis ini.

Teknik pengumpulan data yang digunakan dalam penelitian ini yaitu teknik baca dan catat. Teknik baca yaitu membaca teks atau buku dengan tujuan mengetahui isi keseluruhan teks atau buku tersebut. Teknik baca dalam penelitian ini dilakukan dengan cara membaca teks berita yang terdapat dalam surat kabar Tempo. Peneliti juga menggunakan teknik catat dalam pengumpulan data. Teknik catat digunakan untuk mencatat bentuk data yang terdapat dalam sumbernya saat melakukan pengumpulan data (Mahsun, dalam Hafizin, et.al, 2019). Teknik catat dilakukan dengan cara mencatat kata-kata atau kalimat-kalimat yang termasuk eufemisme dengan unsur-unsur teks berita dalam berita utama surat kabar Tempo. 
Teknik analisis data dalam penelitian ini menggunakan metode deskriptif kualitatif dengan tujuan mendeskripsikan implementasi eufemisme dalam berita utama surat kabar Tempo sebagai bahan ajar bahasa Indonesia di SMP. Langkah pertama yaitu peneliti membaca surat kabar Tempo, selanjutnya melakukan pengumpulan data eufemisme yang ada pada berita utama surat kabar Tempo dan melakukan pengelompokan data penggunaan eufemisme yang terdapat dalam surat kabar Tempo sesuai dengan unsur-unsur teks berita. Langkah selanjutnya yaitu peneliti melakukan analisis implementasi eufemisme dalam berita utama surat kabar Tempo dengan bahan ajar bahasa Indonesia di SMP. Langkah terakhir yaitu menarik simpulan.

\section{HASIL DAN PEMBAHASAN}

Eufemisme dalam berita utama surat kabar Tempo dapat dimanfaatkan sebagai bahan ajar dalam pelajaran bahasa Indonesia kurikulum 2013. Pemilihan bahan ajar meliputi penentuan jenis materi, ruang lingkup, urutan penyajian, perlakuan (treatment), terhadap materi pelajaran, dan sebagainya (Aisyah, dkk, 2020). Eufemisme dalam penelitian ini difokuskan pada teks berita. Berita adalah suatu laporan tercepat mengenai fakta atau ide terbaru yang menarik, benar dan atau penting bagi sebagian besar khalayak, melalui media berkala seperti surat kabar, radio, teleisi, atau media online internet (Sumadiria, dalam Kurniasari, dan Laili, 2019). Sedangkan ciri-ciri teks berita adalah berita harus memuat fakta yang nyata, berita yang dimuat adalah peristiwa yang jarang terjadi, disebut juga unik atau anti-mainstream, aktual yaitu peristiwa yang disajikan harus baru atau paling update, tanpa rekayasa, memberikan informasi dan keterangan waktu serta tempat yang jelas, menggunakan bahasa baku atau formal, tidak mencantumkan opini, judul harus mewakili seluruh isi, penggunaan bahasa bisa dipahami pembaca, kronologis atau alur peristiwanya dimuat secara berurutan, dan yang terakhir bersifat objektif (Lestari, dkk, dalam Kurniasari, dan Laili, 2019). Materi teks berita diajarkan di kelas VIII salah satunya yaitu unsur-unsur teks berita pada tabel 1. KD (Kompetensi Dasar) dan indikator sebagai berikut.

Tabel 1. KD dan indikator

\section{Kompetensi Dasar Indikator}

3.1 Mengidentifiasi unsur-unsur teks
berita (membanggakan dan memotivasi)
yang didengar dan dibaca

3.1 Mengidentifiasi unsur-unsur teks berita (membanggakan dan
yang didengar dan dibaca
3.1.1 Menemukan unsur-unsur teks berita yang didengar dan dibaca
3.1.2 Menguraikan unsur-unsur teks berita yang didengar dan dibaca

Teks berita merupakan teks yang menyajikan informasi secara aktual. Teks berita memiliki unsur-unsur kelengkapan berita yaitu $5 \mathrm{~W}+1 \mathrm{H}$ what (apa), who (siapa), where (di mana), when (kapan), why (mengapa), dan how (bagaimana). Keenam pertanyaan tersebut merupakan cara yang tepat untuk menentukan unsur-unsur teks berita. Penelitian ini menggunakan berita yang terdapat eufemisme dalam berita utama surat kabar Tempo sebagai berikut. 
Tabel 2. Unsur-Unsur Teks Berita

"Ridwan Kamil dan Atalia Praratya Rayakan Tahun Baru Bersama Keluarga Pemulung"

\begin{tabular}{|c|c|c|}
\hline No & $\begin{array}{c}\text { Unsur-unsur } \\
\text { teks Berita }\end{array}$ & Kutipan \\
\hline 1. & What & $\begin{array}{l}\text { Keduanya mendatangi kediaman keluarga pemulung tersebut } \\
\text { dan menyempatkan waktu untuk makan bersama. }\end{array}$ \\
\hline 2. & Who & Ridwan Kamil bersama sang istri. \\
\hline 3. & Where & Tulis Ridwan Kamil di Instagram pribadinya. \\
\hline 4. & When & Pada Kamis, 31 Desember 2020. \\
\hline 5. & Why & $\begin{array}{l}\text { Pemulung yang kemarin sempat viral karena harus membawa } \\
\text { anak bayinya setiap hari ke lapangan karena istrinya sakit. }\end{array}$ \\
\hline 6. & How & $\begin{array}{l}\text { Kedatangan Ridwan Kamil dan Atalia Praratya juga sekaligus } \\
\text { membawa kabar gembira bagi keluarga Pak Dede yang diangkat } \\
\text { sebagai pengurus taman. Dengan begitu, Pak Dede tidak perlu } \\
\text { lagi bekerja sebagai pemulung dan perekonomian keluarganya } \\
\text { akan lebih baik. }\end{array}$ \\
\hline
\end{tabular}

Pada tabel 2 unsur-unsur teks berita dengan judul "Ridwan Kamil dan Atalia Praratya Rayakan Tahun Baru Bersama Keluarga Pemulung" terdapat eufemisme berupa kata pemulung. Dalam Kamus Besar Bahasa Indonesia Edisi Kelima (Tim penyusun, 2016), kata pemulung memiliki arti orang yang mencari nafkah dengan jalan mencari dan memungut serta memanfaatkan barang bekas untuk dijual kepada pengusaha yang akan mengelolanya kembali menjadi barang komoditas. Kata pemulung dalam teks tersebut digunakan untuk menghargai pekerjaan seseorang. Penggunaan kata pemulung di sini digunakan untuk menggantikan seseorang yang bekerja sebagai pemungut sampah atau barang-barang bekas. Ketika membaca teks tersebut, secara tidak langsung peserta didik memahami bahwa menghormati pekerjaan seseorang itu harus dilakukan dengan cara memperhalus kata atau kalimat yang akan diucapkan. Hal ini dapat membuat peserta didik terhindar dari disfemisme.

Pada tabel 3 unsur-unsur teks berita dengan judul "Natal dan Tahun Baru, Omzet Penjualan Cokelat dan Kartu Ucapan Naik Drastis" terdapat eufemisme berupa kata difabel. Kata difabel merupakan serapan dari bahasa Inggris yaitu different ability. Dalam Kamus Besar Bahasa Indonesia Edisi Kelima (Tim penyusun, 2016), difabel memiliki arti penyandang cacat. Difabel juga dapat diartikan seseorang berkebutuhan khusus. Penggunaan kata difabel dalam teks tersebut bertujuan untuk menghindari ungkapan kasar untuk menyebut seseorang yang memiliki kekurangan seperti orang cacat atau orang yang tidak normal. Dari berita tersebut, eufemisme menjadi salah satu alternatif yang dapat digunakan peserta didik untuk memanipulasi kata-kata yang tidak santun, sehingga tidak menimbulkan dampak negatif bagi peserta didik ketika bertemu dengan seseorang yang berkebutuhan khusus. 
Tabel 3. Unsur-unsur Teks Berita

"Natal dan Tahun Baru, Omzet Penjualan Cokelat dan Kartu Ucapan Naik Drastis"

\begin{tabular}{|c|c|c|}
\hline No & $\begin{array}{l}\text { Unsur-unsur teks } \\
\text { Berita }\end{array}$ & Kutipan \\
\hline 1. & What & $\begin{array}{l}\text { Momen Natal dan tahun baru memicu peningkatan } \\
\text { transaksi berbagai produk. }\end{array}$ \\
\hline 2. & Who & Tisa Aunilla (42) pemilik usaha Pipiltin Cocoa. \\
\hline 3. & Where & $\begin{array}{l}\text { Mulai fokus memanfaatkan platform digital } \\
\text { Tokopedia }\end{array}$ \\
\hline 4. & When & Sejak Maret 2020. \\
\hline 5. & Why & $\begin{array}{l}\text { "Omzet kami menurun lebih dari } 50 \text { persen karena } \\
\text { pandemi. Kami akhirnya mengubah strategi } \\
\text { penjualan menjadi online agar bisnis tetap berjalan," } \\
\text { kata Tissa }\end{array}$ \\
\hline 6. & How & $\begin{array}{l}\text { Saat menjelang Natal, Vendy menjelaskan bahwa } \\
\text { kertas kado dan kartu ucapan menjadi produk paling } \\
\text { laris. Selain berbisnis, Harvest juga rutin } \\
\text { membagikan donasi berupa paket alat tulis bagi } \\
\text { anak-anak difabel dan sejumlah panti asuhan }\end{array}$ \\
\hline
\end{tabular}

Tabel 4. Unsur-unsur Teks Berita

\begin{tabular}{ccc} 
& "Vaksin Covid-19 untuk Lansia Belum Tersedia, Ini Kata Menkes" \\
\hline No & $\begin{array}{c}\text { Unsur-unsur teks } \\
\text { Berita }\end{array}$ & Kutipan \\
\hline
\end{tabular}

1. What Pemerintah terus mengupayakan agar masyarakat

2. Who

lanjut usia bisa mendapat vaksin Covid-19.

Menteri Kesehatan Budi Gunadi Sadikin menjelaskan untuk memastikan vaksin bisa

3. Where digunakan pada usia di atas 60 tahun butuh waktu. Tapi, vaksin ini yang diuji klinis di luar Bandung, seperti yang dilakukan di Turki, di Brasil, juga diberikan ke orang-orang dengan grup usia diatas 60 tahun," jelasnya Selasa, 29 Desember 2020.

4. When Selasa, 29 Desember 2020.

5. Why "Dan karena vaksin kita yang dapat yang akan datang nanti ada empat jenis (dari empat perusahaan), otomatis keragaman itu akan ada. Itu sebabnya kalau kita lihat tadi tahapannya lansia kita taruh agak ke belakang karena kita ingin memastikan bahwa semua secara scientific terkait pemberian vaksin ke grup lansia ini, BPOM sudah feel comfortable," umbuhnya.

6. How Budi menegaskan kemungkinan vaksin-vaksin dari perusahaan di luar Sinovac, seperti Novavax, AstraZeneca, atau Pfizer, akan tiba pada semester II/2021 atau paling cepat akhir Kuartal II/2021. 
Pada tabel 4 unsur-unsur teks berita berjudul "Vaksin Covid-19 untuk Lansia Belum Tersedia, Ini Kata Menkes" terdapat eufemisme pada kata lansia. Lansia merupakan akronim dari lanjut usia. Dalam Kamus Besar Bahasa Indonesia Edisi Kelima (Tim penyusun, 2016), dijelaskan lanjut usia adalah seseorang yang sudah berumur tua. Seseorang yang masuk dalam kategori lansia yaitu berusia lebih dari 60 tahun. Penggunaan kata lansia dinilai lebih halus daripada tua bangka. Penghalusan makna kata juga bertujuan untuk menciptakan bahasa komunikasi yang sopan dan santun terutama bagi peserta didik sekolah menengah pertama.

Tabel 5. Unsur-unsur Teks Berita

\begin{tabular}{|c|c|c|}
\hline No & $\begin{array}{l}\text { Unsur-unsur teks } \\
\text { Berita }\end{array}$ & Kutipan \\
\hline 1. & What & $\begin{array}{l}\text { Leya Cattleya, bersama sejumlah sahabatnya di } \\
\text { komunitas EMPU, terus bergerak membantu } \\
\text { kelompok-kelompok perempuan marginal }\end{array}$ \\
\hline 2. & Who & Leya Cattleya \\
\hline 3. & Where & $\begin{array}{l}\text { Di kota seperti di Bekasi dan Jakarta, banyak } \\
\text { penjual jamu yang mudik. Sebagian masih bertahan. } \\
\text { Kami coba mengumpulkan mereka untuk } \\
\text { mendapatkan bimbingan teknis. Kami mencoba } \\
\text { mengumpulakan mereka untuk mendapat } \\
\text { bimibngan teksnis. Dari } 200 \text { yang terdata, ada } 70 \\
\text { orang yang ikut acara secara daring. Dari } \\
\text { Yogyakarta, Serang, Palu, Sragen, hingga Maluku }\end{array}$ \\
\hline 4. & When & $\begin{array}{l}\text { Memasuki Maret 2020, pandemi Covid-19 } \\
\text { diumumkan. }\end{array}$ \\
\hline 5. & Why & $\begin{array}{l}\text { Ada ide membuat masker dengan mencontoh } \\
\text { masker yang ada di Republik Cek. Saat itu, } \\
\text { komunitas batik EMPU mulai kehilangan } \\
\text { pelanggan. }\end{array}$ \\
\hline 6. & How & $\begin{array}{l}\text { Sebenarnya ini berawal dari kumpul-kumpul } \\
\text { mewujudkan tekstil ramah lingkungan dengan } \\
\text { pewarna alam. Kebetulan adik saya berkolaborasi } \\
\text { dengan perajin warna alam. }\end{array}$ \\
\hline
\end{tabular}

Pada tabel 5 unsur-unsur teks berita berjudul "Letya Cattleya: Perempuan Sektor informal Perlu Meningkatkan Ekonominya" terdapat dua jenis eufemisme, yang pertama yaitu kata kelompok. Dalam Kamus Besar Bahasa Indonesia Edisi Kelima (Tim penyusun, 2016), kelompok memiliki arti kumpulan, gerombolan, geng, dan golongan. Penggunaan kata kelompok dalam kalimat tersebut dinilai lebih sopan dibandingkan dengan gerombolan atau geng yang terkesan kasar. Kata kelompok termasuk dalam bentuk eufemisme berupa satu kata yang digunakan untuk mengganti kata lain. Kedua, terdapat eufemisme pada ungkapan perempuan marginal. Dalam Kamus Besar Bahasa Indonesia Edisi Kelima (Tim penyusun, 2016), marginal memiliki arti berada di pinggir atau dapat diartikan perempuan pinggiran, perempuan miskin, perempuan yang memiliki ekonomi rendah. Ungkapan perempuan marginal 
dalam kalimat tersebut untuk menghaluskan makna kata dan untuk menghargai kondisi seseorang.

Pada tabel 6 unsur-unsur teks berita berjudul "Kekerasan yang Berulang" terdapat beberapa eufemisme. Pertama, kata jenazah dalam berita tersebut merupakan eufemisme. Pemakaian jenazah dinilai lebih halus untuk menggantikan kata mayat. Kedua, kata brutal dalam Kamus Besar Bahasa Indonesia Edisi Kelima (Tim penyusun, 2016), memiliki arti kejam, kasar, atau biadab. Ketiga, frasa menghabisi nyawa yang memiliki arti membunuh. Ketika peserta didik membaca berita pasti sering menjumpai kata-kata jenazah, brutal, dan frasa menghabisi nyawa. Kata-kata tersebut sering digunakan dalam berita untuk menghaluskan ucapan.

Tabel 6. Unsur-unsur Teks Berita

"Kekerasan yang Berulang"

\begin{tabular}{lcc}
\hline No & $\begin{array}{c}\text { Unsur-unsur teks } \\
\text { Berita }\end{array}$ & Kutipan \\
\hline 1. & What
\end{tabular}

1. What Bekas luka tembak pada enam jenazah anggota Front Pembela Islam (FPI) seperti yang dijelaskan keluarganya di depan Komisi III DPR menunjukkan betapa brutalnya aparat yang menghabisi nyawa mereka.

2. Who

3. Where

4. When

5. Why

6. How
Muhammad Rizieq Syihab.

Sejumlah saksi mata menuturkan, setidaknya empat dari enam anggota FPI itu masih bisa berjalan ketika polisi melumpuhkan mereka di Kilometer 50 jalan tol Jakarta-Cikampek.

Senin, 14 Desember 2020.

Penjelasan polisi sejauh ini tak membuat terang pelbagai kejanggalan. Karena itu, wajar bila muncul spekulasi bahwa anggota FPI itu telah menjadi korban pembunuhan di jalur hukum alias extrajudicial killing- kejahatan yang menabrak undang-undang dan kovenan internasional tentang hak asasi manusia (HAM).

Di atas kertas, Peraturan Kepala Polri Nomor 1 Tahun 2009 telah menjabarkan dalam situasi apa polisi bida menembak pelaku kejahatan. Polisi hanya boleh menembak ketika nyawa aparat atau masyarakat terancam. Penembakan hanya dibolehkan ketika polisi tak punya pilihan

Dari lima judul teks berita di atas, setiap teks berita memiliki kelengkapan unsurunsur yaitu $5 \mathrm{~W}+1 \mathrm{H}$. Penggunaan $5 \mathrm{~W}+1 \mathrm{H}$ memiliki fungsi yang sangat penting bagi pembaca karena pembaca dapat memahami isi berita tanpa harus membaca keseluruhan isi berita. Berita yang paling banyak menggunakan ungkapan eufemisme yaitu berita politik. Penggunaan eufemisme berita utama surat kabar Tempo pada unsur-unsur teks berita diatas dapat diterapkan sebagai contoh bagi peserta didik dalam berkomunikasi atau berbahasa yang santun dengan orang lain didalam kelas ataupun di luar kelas. Penggunaan eufemisme dalam berkomunikasi dapat menghindari peserta didik dari 
disfemisme dengan mengubah kata-kata yang nilai kasar menjadi halus dan sopan. Tugas seorang guru bahasa Indonesia harus bisa memotivasi peserta didik untuk terus menambah pengetahuan serta wawasan supaya peserta didik tidak ketinggalan oleh kemajuan zaman, bisa mengendalikan diri untuk tidak terbawa arus negatif, serta membuat peserta didik menguasai materi yang sedang dipelajari (Murniasih, 2017).

Pembelajaran bahasa Indonesia khususnya teks berita tidak selalu mengacu pada berita yang ada di buku teks. Guru dapat menggunakan surat kabar sebagai tambahan sumber bahan ajar. Contoh berita yang ada pada buku teks sudah terlalu usang karena peristiwa yang terjadi sudah tidak aktual lagi. Media belajar yang paling aktual untuk mengetahui informasi atau peristiwa yang terjadi saat ini yaitu dengan koran online. Teks berita pada surat kabar Tempo dapat dimanfaatkan sebagai bahan ajar yang disesuaikan dengan materi pelajaran teks berita. Berdasarkan analisis dari lima judul teks berita diatas maka dapat disimpulkan bahwa eufemisme dapat diimplementasikan dengan pembelajaran materi teks berita bahasa Indonesia di SMP.

\section{SIMPULAN}

Dari hasil penelitian eufemisme dalam berita utama surat kabar Tempo dapat diimplementasikan sebagai bahan ajar bahasa Indonesia materi teks berita kelas VIII. Hal ini dapat dilihat pada berita utama surat kabar Tempo terdapat eufemisme di dalam unsur-unsur teks berita. Kompetensi dasar yang dapat digunakan yaitu KD 3.1 mengidentifikasi unsur-unsur teks berita (membanggakan dan memotivasi) yang didengar dan dibaca dengan indikator pencapaian menemukan unsur-unsur teks berita yang didengar dan dibaca dan menguraikan unsur-unsur teks berita yang didengar dan dibaca. Eufemisme yang ditemukan yaitu pemulung, difabel, lansia, kelompok, perempuan marginal, jenazah, brutal, dan menghabisi nyawa. Penggunaan eufemisme dalam berita utama surat kabar Tempo sebagai bahan ajar berperan untuk pembentukan moral baik kepada peserta didik sekolah menengah pertama karena memberikan dampak positif untuk perkembangan wawasan dalam berkomunikasi dan menghargai orang lain.

\section{DAFTAR PUSTAKA}

Aisyah, dkk. (2020). "Bahan Ajar sebagai Bagian dalam Kajian Problematika Pembelajaran Bahasa Indonesia”. Jurnal Salaka, 2 (1): 62-65.

Badelah, dkk. (2019). "Tindak Tutur Kesantunan Guru dan Siswa dalam Pembelajaran Bahasa Indonesia di SMP Negeri 2 Sakra: Tinjauan Pragmatik". Lingua, 16 (2): 219-234.

Delisnawati, dkk. (2019). "Kemampuan Menentukan Struktur dan Unsur Kebahasaan Teks Berita Siswa Kelas VIII SMP Negeri 1 Barangka. Jurnal BASTRA (Bahasa dan Sastra), 4(4): 559-570.

Febrianjaya, Abdan Syakur, et. al. (2013). "Penggunaan Eufemisme dan Disfemisme Pada Tajuk Rencana Serta Implikasinya Terhadap Pembelajaran”. Jurnal Kata (Bahasa, Sastra, dan Pembelajarannya), 1 (6): 1-8. 
Hafizin, dkk. (2019). "Disfemisme dan Eufemisme dalam Teks Berita Sepak Bola di Televisi Nasional". Transformatika: Jurnal Bahasa, Sastra, dan Pengajarannya, 3(2): 104-114.

Hidayat, Arif. (2011). "Pembelajaran Menulis Teks Berita”. INSANIA, 16(3): 283-293.

Hidayatullah, dkk. (2018). "Korelasi Menyimak Berita dengan Keterampilan Teks Berita Siswa Kelas VIII SMP Negeri 2 Batusangkar. Jurnal Pendidikan Bahasa dan Sastra Indonesia, 7(4): 44-51.

Mahsun, M.S. (2014). Metode Penelitian Bahasa Metode Penelitian Bahasa: Tahapan Strategi Metode dan Tekniknya. Jakarta: Raja Grafindo Persada.

Kurniasari, Arisya Sinta, dan Laili Etika Rahmawati. (2019). Keakuratan Teks Berita pada Materi Ajar Bahasa Indonesia bagi Siswa Kelas VIII di SMP N 3 Polanharjo. Skripsi thesis, Universitas Muhammadiyah Surakarta.

Murniasih, Sugi. (2017). "Pengembangan Model Bahan Ajar Menulis Berita Berbasis Koran Linggau Pos Siswa Kelas VIII SMP Negeri Sumber Rejo". Jurnal KIBASP (Kajian Bahasa, Sastra, dan Pengajarannya), 1(1): 12-31.

Narimawati, Umi. (2008). Metode Penelitian Kualitatif dan Kuantitatif: Teori dan Aplikasi. Bandung: Agung Media.

Pendari, Vonny Julia, dan Amril Amir. (2019). "Diksi dalam Teks Berita Kelas VIII SMP Negeri 6 Pariaman". Jurnal Pendidikan Bahasa dan Sastra Indonesia, 8(3): 455-460.

Putri, Devi Yanti Sari. 2020. Peningkatan Kemampuan Menulis Teks Berita Dengan Teknik Pelatihan Terbimbing pada Siswa Kelas VIII F SMPN 11 Pontianak. Cakrawala Linguista, 3(2): 90-97.

Rimayanti, Ade Ina, dan Jaja. (2018). "Pengembangan Bahan Ajar Teks Eksplanasi Berdasarkan Berita media Massa Cetak. Jurnal Tuturan, 7(2): 857-862.

Sagala, Liani Hasnita Ulfa Br. (2020). "Kajian Eufemisme dan Disfemisme pada Komentar Para Netizen dalam Youtube Berita Kumparan.com (Edisi Menko Polhukam Wiranto Ditusuk Orang di Pandeglang”. Seminar Internasional Riksa Bahasa.

Setiawaty, R. \& Wahyudi, B. (2018). "Bentuk dan Fungsi Eufemisme dalam Komentar Akun Facebook Presiden Joko Widodo Sebagai Bahan Ajar Bahasa Indonesia". The 7th University Research Colloqium 2018. STIKES PKU Muhammadiyah: Surakarta.

Sugiyono. (2006). Statistika Untuk Penelitian. Bandung: CV. Alfabeta. 


\section{PRASI JURNAL BAHASA, SENI, DAN PENGAIARANNYA}

VOL. 16 | No. 01 | Juni 2021

ISSN: Print 1693-6124 - Online 2614-1116

Undiksha| DOl:http://dx.doi.org/10.23887/prasi.v16i01.34100 |https://ejournal.undiksha.ac.id/index.php/PRASI

Sugiyono. (2011). Metode Penelitian Kuantitatif, Kualitatif, dan R\&D. Bandung: Alfabet.

Sukmawati, Diah, Agus Budi Wahyudi. (2018). Analisis Register dan Fungsi Bahasa dalam Teks Berita Koran Suara Merdeka Edisi April 2018 dan Implementasinya Sebagai Bahan Ajar Bahasa Indonesia di SMP Kelas VIII. Universitas Muhammadiyah Surakarta.

Tim Penyusun Kamus Besar Bahasa Indonesia. (2016). Kamus Besar Bahasa Indonesia. Jakarta: Balai Pustaka. 